\title{
Isolation of Rat Hepatoma Cell Variants Selectively Resistant to Dexamethasone Inhibition of Plasminogen Activator
}

\author{
SARAH CARLSON SEIFERT ${ }^{1}$ AND THOMAS D. GELEHRTER ${ }^{2}$ \\ Departments of Human Genetics and Internal Medicine, University of Michigan \\ Medical School, Ann Arbor, Michigan 48109
}

\begin{abstract}
Glucocorticoids induce several phenotypic changes in rat hepatoma cells in tissue culture, including the inhibition of plasminogen activator activity. Variant cell lines resistant to dexamethasone inhibition of plasminogen activator activity have been isolated using an agar-fibrin overlay technique to identify colonies with fibrinolytic (plasminogen activator) activity. The variants are resistant to concentrations of dexamethasone 1,000 times that necessary to completely inhibit plasminogen activator activity in wild-type cells. The variant phenotype has been inherited in a stable manner for more than 300 generations in continuous culture in the absence of dexamethasone. These variants are unique in that the resistance is not secondary to defective or absent glucocorticoid receptors but is due to a lesion specific for regulation of plasminogen activator. Fluctuation analyses support the hypothesis that resistance to dexamethasone arises randomly and is not induced by dexamethasone. Because HTC cells are heteroploid and karyotypically highly variable, variants are thought to arise primarily by chromosomal segregation events. These variants provide a valuable tool for studying the mechanism of hormonal regulation of plasminogen activator as well as the role of proteases in hormonal regulation of membrane functions.
\end{abstract}

It is generally agreed that the action of steroid hormones is mediated by specific cytoplasmic receptors. The hormone binds to the receptor, forming a complex that is then transferred into the nucleus, where it binds to chromatin and stimulates the accumulation of specific messenger RNAs (Rousseau, '75). Mouse lymphoma cells resistant to the cytotoxic effects of glucocorticoids have been isolated, which have deficient or defective steroid receptors, and these variants have been useful for analyzing the early steps in steroid action (Pfahl et al., '78; Sibley and Tomkins, '74; Yamamoto et al., '76).

In HTC ${ }^{3}$ cells, an established line of rat hepatoma cells, glucocorticoids induce several well-studied responses without affecting the growth of the cells, thus providing a system in which to study steps involved in glucocorticoid regulation beyond nuclear binding of the hormone-receptor complex. Included among these hormonal responses are the induction of tyrosine aminotransferase, and changes in several membrane properties such as (a) the rapid and reversible inhibition of the rate of influx of selected amino acids (Risser and Gelehrter, '73; McDonald and Gelehrter, '77), (b) a decrease in the number of microvilli on the surface of HTC cells in suspension culture, as assessed by scanning electron microscopy, ${ }^{4}$ (c) an increase in the adhesiveness of HTC cells (Ballard and Tomkins, '70; Fredin et al., '79), and (d) a decrease in the activity of plasminogen activator, a membrane-associated protease (Wigler et al., '75; Carlson and Gelehrter, '77; Seifert and Gelehrter, '78). We report here the isolation of several lines of HTC cells resistant to the inhibitory effect of dexamethasone on

\footnotetext{
Received Oct. 5, '78. Accepted Jan. 3, '79.

'Current address: Department of Internal Medicine, University of lowa, Jowa City, Iowa 52242.

${ }^{2}$ To whom all correspondence should be addressed.

Abbreviations: HTC, hepatoma tissue culture; EMS, ethyl methanesulfonate; MEM, minimal essential medium; UV, ul. traviolet light.

${ }^{4}$ Berliner, J., and T. D. Gelehrter, unpublished observations.
} 
plasminogen activator, using an agar-fibrin overlay technique to detect protease activity in individual colonies of cells (Jones et al., '75). Some of the properties of these unique glucocorticoid-resistant variant cell lines are described in this report. Combined genetic and biochemical analysis of such dexamethasoneresistant variants should facilitate study of hormonal regulation of plasminogen activator as well as the role of proteases in hormonal regulation of membrane functions.

\section{MATERIALS AND METHODS}

\section{Materials}

Acid-treated fetal calf serum was prepared as described by Strickland and Beers ('76). Fibrinogen $(77 \%$ clottable) was purchased from Calbiochem and purified as described by Strickland and Beers (76). Plasminogen-free fetal calf serum was a gift from Doctor Sidney Strickland. Bovine thrombin was purchased from Parke-Davis. ${ }^{125}$ I-fibrinogen was a gift from Abbott Laboratories. Dexamethasone was a gift from Merck and Company. Ethyl methanesulfonate (EMS) was purchased from Eastman Kodak. All other components were of reagent grade.

\section{HTC cell cultures}

HTC cells are an established line of rat hepatoma cells which have been in continuous culture for the past 13 years (Thompson et al., '66). The cells were grown in monolayer or spinner culture without antibiotics in Eagle's minimal essential medium (MEM) for suspension culture modified to contain $50 \mathrm{mM}$ Tricine, $0.5 \mathrm{~g} / 1 \mathrm{NaHCO}_{3}, 2 \mathrm{mM}$ glutamine, $5 \%$ calf serum, and $5 \%$ fetal calf serum.

\section{Agar-fibrin overlay technique}

An agar-fibrin overlay technique was used to detect the production of plasminogen activator by individual colonies of HTC cells as previously described (Carlson and Gelehrter, '77). Briefly, colonies of HTC cells (60-100 colonies per dish) were grown on $60-\mathrm{mm}$ tissue culture dishes for five to seven days, and overlaid with agar in which an opalescent fibrin clot forms. Because the medium also contains acid-treated fetal calf serum as a source of plasminogen, colonies producing and secreting plasminogen activator convert the plasminogen to plasmin, which in turn lysis the fibrin, forming a clear area, or plaque over the colony. This technique is not destructive, and selected colonies of cells can be removed through the agar and propagated.

\section{Measurement of intracellular plasminogen activator activity}

HTC cells were grown to $80-90 \%$ confluence on $60-\mathrm{mm}$ tissue culture dishes and then incubated in serum-free medium with or without dexamethasone for 18 hours at $37^{\circ}$. The medium was removed from the cells, and the plates were washed with phosphate buffered saline. The cells were scraped off the dish with a rubber policeman into $1 \mathrm{ml}$ of $0.2 \%$ Triton $\mathrm{X}$. 100 . The suspension was repeatedly pipetted up and down for one minute with a Pasteur pipette, centrifuged for five minutes at 1,200 $x g$ and the supernatant fraction decanted and stored at $-20^{\circ}$. One $\mathrm{ml}$ samples consisting of $0.2 \mathrm{ml}$ cell lysate (diluted with $0.2 \%$ of Triton X-100 to $0.1 \mathrm{mg}$ protein per $0.2 \mathrm{ml}$ ), $0.775 \mathrm{ml}$ of $0.1 \mathrm{M}$ Tris $(\mathrm{pH} 8.1$ ), and $0.025 \mathrm{ml}$ acid-treated fetal calf serum (as a source of plasminogen) were added to $16-\mathrm{mm}$ wells of a Linbro 24-well tissue culture dish coated with ${ }^{125} \mathrm{I}$-fibrin, and incubated in a humidified incubator at $37^{\circ}$ for ten hours. Blanks were added to several wells to determine back. ground and consisted of the same mixture, but with $0.2 \mathrm{ml}$ of $0.2 \%$ Triton X-100 in place of the cell lysate. Total radioactivity per well was determined by averaging several wells in which only trypsin $(0.25 \%)$ had been added. The amount of plasminogen activator activity is expressed as a percentage of the radioactivity solubilized by trypsin, after subtraction of the radioactivity released by the blanks. All values are corrected for amount of protein in the sample.

\section{${ }^{125}$ I-fibrin plates}

One-fourth milliliter of a solution containing $0.12 \mathrm{mg} / \mathrm{ml}$ fibrinogen in 1 part calcium and magnesium-free phosphate buffered saline to 11 parts $\mathrm{H}_{2} \mathrm{O}$ and containing 400,000 $\mathrm{cpm} / \mathrm{ml}$ of ${ }^{125} \mathrm{I}$-fibrinogen was added to each well of Linbro 24-well (16 mm) tissue culture dishes and allowed to dry for two to four days at $37^{\circ}$. Plates were stored at room temperature. Just prior to use, dishes were incubated for two hours at $37^{\circ}$ with $0.5 \mathrm{ml}$ of MEM containing $5 \%$ fetal calf serum to convert the fibrinogen to fibrin. The medium was then removed and the plates washed twice with $0.1 \mathrm{M}$ Tris ( $\mathrm{pH}$ 8.1). Radioactivity removed by this step was less than $15 \%$ of that solubilized by trypsin.

\section{Determination of cloning efficiencies}

One hundred to two hundred cells were plated on $60-\mathrm{mm}$ tissue culture dishes and 
grown for seven to ten days in $\alpha$-modification of Eagle's medium ( $\alpha$-MEM) (Stanners et al., '71) with $10 \%$ fetal calf serum with and without $0.1 \mu \mathrm{M}$ dexamethasone. The colonies were rinsed with phosphate buffered saline, fixed with ethanol and stained with $0.1 \%$ crystal violet prior to counting.

Fluctuation analysis.

A freshly cloned population of HTC cells was grown to approximately $3 \times 10^{3}$ cells. The cells were then subcloned in 96-well tissue culture plates (Falcon) and the wells were checked microscopically to insure that each subclone used originated from a single cell. Both the subclones and cells of the original clone were trypsinized, plated in several 60 $\mathrm{mm}$ dishes, allowed to grow into clones for six days, and incubated with $1 \mu \mathrm{M}$ dexamethasone overnight. A few plates were fixed with ethanol, stained with $0.1 \%$ crystal violet and the number of colonies per plate counted. The remaining plates were covered by the agarfibrin overlay, stained with Coomassie blue stain, and the number of dexamethasone-resistant (plaque-forming) colonies counted.

\section{Mutagenesis}

Cells were plated in $\alpha$-MEM with $10 \%$ fetal calf serum in 60 - or $100-\mathrm{mm}$ dishes and allowed to attach. For treatment with EMS they were then incubated in MEM containing 100 to $600 \mu \mathrm{g} / \mathrm{ml}$ EMS for 18 hours, followed by $\alpha$. MEM with $10 \%$ fetal calf serum in the absence of EMS for eight days. To treat the cells with ultraviolet light (UV), the medium was aspirated, the cells irradiated in open dishes with 100 to 200 ergs using a 15-watt Champion G1518 germicidal UV lamp, peak at $254 \mathrm{~nm}$. The UV flux was $1 \mathrm{Jm}^{-2}$ as determined by a Black-Ray UV meter, Model J-225 (Ultraviolet Products, Inc.). The UV-treated cells were then incubated in $\alpha$-MEM plus $10 \%$ fetal calf serum for eight days. Both EMS and UVtreated cells were then treated with or without $1 \mu \mathrm{M}$ dexamethasone in MEM for 18 hours and the number of plasminogen activator producing colonies in control plates and the number of dexamethasone-resistant colonies determined using the agar-fibrin overlay technique.

\section{Other methods}

Transport of $\alpha$-aminoisobutyric acid was measured as described by Heaton and Gelehrter ('77). Tyrosine aminotransferase was assayed by the method of Spencer and Ge- lehrter (74), and protein by the method of Lowry et al. ('51). Coomassie blue stain was prepared as described by Beers et al. ('75).

\section{RESULTS \\ Dexamethasone inhibition of plasminogen activator}

Plasminogen activator activity was measured quantitatively by solubilization of ${ }^{125}$ Ifibrin. The amount of radioactivity released increased with increasing protein concentration and increasing incubation time, provided that the radioactivity released did not exceed $50 \%$ of the trypsin-soluble radioactivity on the plate. The fibrinolytic activity was completely dependent on the presence of plasminogen; when plasminogen-free acid-treated fetal calf serum was used, the radioactivity released was no greater than background. Direct addition of dexamethasone to the assay had no effect on fibrinolytic activity (Seifert and Gelehrter, '78; Seifert, '78).

Dexamethasone dramatically inhibits plasminogen activator activity in HTC cells. The sensitivity of intracellular plasminogen activator activity to inhibition by dexamethasone was measured over a concentration range of $1 \mathrm{nM}$ to $10 \mu \mathrm{M}$. As shown in figure 1, there is complete inhibition by $10 \mathrm{nM}$ steroid, with half-maximal inhibition at approximately 5 $\mathrm{nM}$, the same concentration that half-maximally induces tyrosine aminotransferase (Rousseau, '75) and half-maximally inhibits $\alpha$-aminoisobutyric acid transport (McDonald and Gelehrter, '77).

\section{Isolation of dexamethasone- resistant variants}

In the absence of dexamethasone, almost all colonies of HTC cells produce plasminogen activator as assessed by the presence of fibrinolytic plaques in the agar-fibrin overlay. Because dexamethasone inhibits plasminogen activator production, few if any plaques occur in the agar-fibrin overlay over dexamethasone-sensitive wild-type cells (Carlson and Gelehrter, '77). However, colonies which are resistant to dexamethasone can be identified by their production of plasminogen activator activity in the presence of hormone, and can be recovered through the agar-fibrin overlay.

When a plaque-forming colony is propagated and retested, the majority, but not all, of the colonies form plaques in the presence of dexamethasone. This is in part due to contamination by nearby dexamethasone-sensi- 


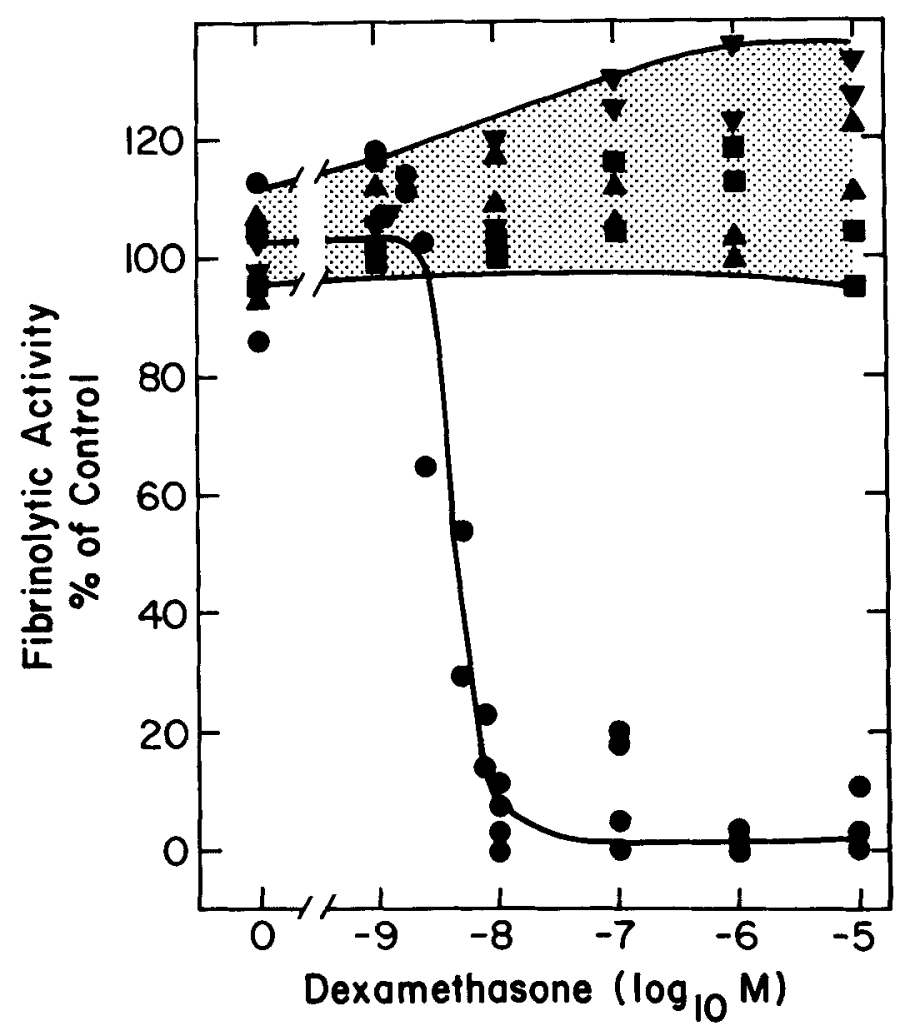

Fig. 1 Concentration dependence of dexamethasone inhibition of plasminogen activator in wild-type and variant HTC cells. Cells were incubated with increasing concentrations of dexamethasone for 18 hours. One hundred micrograms of cell protein were assayed for fibrinolytic activity on ${ }^{125}$ I-fibrin plates for ten hours. In order to facilitate comparison, results for each cell line are expressed as the percentage of the activity of the respective untreated cells. One hundred percent of control activity in wild-type cell extracts released $30 \%$ of the trypsin-soluble radioactivity, whereas $100 \%$ of control activity for the three variant cell lines released approximately $50 \%$ of trypsin-soluble radioactivity. Each point represents the average of duplicate assays per-

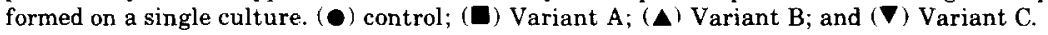

tive cells which are picked out of the agar overlay along with the dexamethasone-resistant cells. It is also in part due to the heterogeneous and karyotypically highly variable nature of HTC cells. However, repeated isolation of such plaque-forming colonies, propagation in the absence of dexamethasone, and retesting by the overlay technique has resulted in the isolation of seven cell lines highly resistant to dexamethasone inhibition of plasminogen activator activity. Essentially all the colonies of a resistant cell line produce fibrinolytic plaques in the presence of dexamethasone, and the size of the plaques is the same as that produced by colonies in the absence of dexamethasone (Carlson and Gelehrter, '77). The original plaque-forming colonies which gave rise to the seven variant cell lines were all isolated from separate culture dishes from four separate experiments, sug. gesting that they represent independent isolates.

\section{Characterization of dexamethasone- resistant variants}

Dexamethasone-resistance of these variants was confirmed by the quantitative ${ }^{125} I$ fibrin assay. The fibrinolytic activity of the variants is approximately two to ten times greater than wild-type activity. This may reflect the isolation procedure in which variants producing large plaques were picked. As shown in figure 1 (shaded portion) variants A, $B$, and $C$ show no inhibition of plasminogen activation by dexamethasone at concentrations up to $10 \mu \mathrm{M}$, whereas wild-type cells are completely inhibited by $10 \mathrm{nM}$ dexamethasone. Thus the variants are resistant to 
TABLE 1

Efficiency of plating 1

\begin{tabular}{ccc}
\hline Cell line & Control & Dexamethasone \\
\hline Wild-type & $55 \pm 3$ & $51 \pm 5$ \\
Var A & $48 \pm 8$ & $47 \pm 6$ \\
Var B & $55 \pm 8$ & $63 \pm 4$ \\
Var C & $43 \pm 11$ & $44 \pm 3$ \\
\hline
\end{tabular}

Mean $\pm \mathrm{SEM}, \mathrm{n}=3$.

TABLE 2

Dexamethasone induction of tyrosine aminotransferase

\begin{tabular}{cccc} 
& Control & Dexamethasone & Fold increase \\
\hline Wild-type & 45 & 243 & 5.4 \\
Var A & 9 & 52 & 5.8 \\
Var B & 12 & 77 & 6.4 \\
Var C & 20 & 134 & 6.7 \\
\hline
\end{tabular}

Wild-type and variant HTC cells were incubated in suspension culture in serum-free medium with or without $0.1 \mu \mathrm{M}$ dexamethasone for 24 hours and assayed for tyrosine aminotransferase. Activity is ex. pressed as $\mathrm{mU} \cdot \mathrm{mg}$ protein ${ }^{-1}$, One $\mathrm{mU}$ equals one nmole product formed per minute.

steroid concentrations 1,000 times higher than that necessary to completely inhibit wild-type HTC cells.

Each variant appears to possess a distinct morphology; however, there appears to be no single consistent morphology associated with resistance to dexamethasone inhibition of plasminogen activator.

The cloning efficiencies of wild-type and three of the variant cell lines are shown in table 1 . The plating efficiencies range from $40-60 \%$ and are not altered by dexamethasone. The growth rates of both variant and normal cells in monolayer are also not affected by dexamethasone. Both wild-type and variant cell lines are capable of growing in suspension as well as monolayer culture. The fact that dexamethasone does not alter cloning efficiency or growth rate in wild-type cells, in which plasminogen activator activity is inhibited, nor in variant cells, in which it is not inhibited, clearly dissociates regulation of growth from regulation of this protease activity in HTC cells.

In order to determine whether these variants possess normal dexamethasone receptor function, induction of tyrosine aminotransferase, a well-characterized, non-membraneassociated response in H'TC cells, was tested. Dexamethasone induction of tyrosine aminotransferase in wild-type and variant HTC cells

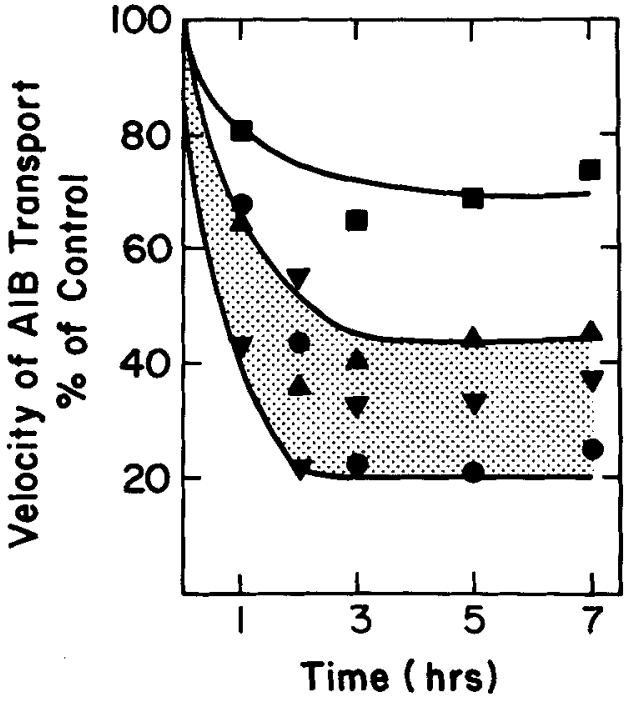

Fig. 2 Time course of dexamethasone inhibition of AIB transport. Wild-type and variant HTC cells were incubated in suspension culture in serum-free medium with $0.1 \%$ albumin with or without $0.1 \mu \mathrm{M}$ dexamethasone. At the times indicated, samples were taken for measurement of initial rate of AIB transport. (C) control; (E) Variant A; (A) Variant B; and ( $\boldsymbol{\nabla})$ Variant $\mathrm{C}$.

is shown in table 2. The basal levels of tyrosine aminotransferase varied from $11-45 \mathrm{mU} / \mathrm{mg}$ protein in wild-type cells with a dexamethasone induction of 3 - to 10 -fold. The variants had basal levels of tyrosine aminotransferase ranging from 9-63 $\mathrm{mU} / \mathrm{mg}$ protein, and all showed dexamethasone induction ranging from 4- to 12-fold. In order for normal wildtype induction to occur, the variants must have normal glucocorticoid receptor function; i.e., dexamethasone binding to the cytoplasmic receptor, and its transfer to the nucleus and binding to chromatin (Thompson and Lippman, '74; Rousseau, '75).

Dexamethasone inhibition of $\alpha$-aminoisobutyric acid transport was tested to determine whether resistance in the variants was specific for inhibition of plasminogen activator, or whether other aspects of membrane function under dexamethasone regulation are also affected. The velocity of transport by wild-type and variant cell lines in the absence of hormone was similar and ranged from 0.8-1.8 $\mathrm{nmol} \cdot \mathrm{min}^{-1} \cdot \mathrm{mg}$ protein ${ }^{-1}$. Figure 2 shows the effect of dexamethasone on $\alpha$-aminoisobutyric acid transport in wild-type and hormone-resistant HTC cells. Variants B and C, and the four other variant lines not shown, show inhibition 
TABLE 3

Fluctuation test

\begin{tabular}{|c|c|c|c|c|c|c|c|}
\hline \multicolumn{4}{|c|}{$\begin{array}{l}\text { Number of dexamethasone-resistant colonies } \\
\text { in each subclone }\end{array}$} & \multicolumn{4}{|c|}{$\begin{array}{l}\text { Number of dexamethasone-resistant colonies in } \\
\text { samples of the original clone }\end{array}$} \\
\hline $\begin{array}{l}\text { Subclone } \\
\text { number }\end{array}$ & $\begin{array}{c}\text { Total } \\
\text { number of } \\
\text { colonies }\end{array}$ & $\begin{array}{l}\text { Number of } \\
\text { resistant } \\
\text { colonies }\end{array}$ & $\begin{array}{c}\text { Number of } \\
\text { resistant } \\
\text { colonies } / 1,000\end{array}$ & $\begin{array}{l}\text { Sample } \\
\text { number }\end{array}$ & $\begin{array}{c}\text { Total } \\
\text { number of } \\
\text { colonies }\end{array}$ & $\begin{array}{l}\text { Number of } \\
\text { resistant } \\
\text { colonies }\end{array}$ & $\begin{array}{c}\text { Number of } \\
\text { resistant } \\
\text { colonies } / 1,000\end{array}$ \\
\hline 1 & 1,290 & 32 & 25 & 1 & 837 & 21 & 25 \\
\hline 2 & 1,165 & 5 & 4 & 2 & 837 & 20 & 24 \\
\hline 3 & 1,035 & 3 & 3 & 3 & 837 & 31 & 37 \\
\hline 4 & 903 & 102 & 113 & 4 & 837 & 27 & 32 \\
\hline 5 & 669 & 3 & 9 & 5 & 837 & 26 & 31 \\
\hline 6 & 665 & 1 & 2 & 6 & 837 & 31 & 37 \\
\hline 7 & 656 & 7 & 11 & 7 & 837 & 28 & 33 \\
\hline 8 & 590 & 50 & 85 & 8 & 837 & 42 & 50 \\
\hline 9 & 555 & 48 & 86 & & & & \\
\hline 10 & 545 & 25 & 46 & & & & \\
\hline 11 & 470 & 0 & 0 & & & & \\
\hline \multicolumn{4}{|c|}{$\begin{aligned} \overline{\mathrm{X}} & =34.9 \\
\text { Variance } & =1,695.7\end{aligned}$} & & \multicolumn{3}{|c|}{$\begin{aligned} \overline{\mathrm{X}} & =33.6 \\
\text { Variance } & =66.8\end{aligned}$} \\
\hline
\end{tabular}

of $\alpha$-aminoisobutyric acid transport similar in time course and magnitude to that in wildtype cells (fig. 2 shaded area). In contrast, variant $A$ appears to show at least partial resistance to the inhibitory effects of dexamethasone on $\alpha$-aminoisobutyric acid transport. Thus, there is not a general resistance of these variants to all membrane-associated dexamethasone responses.

\section{Origin of dexamethasone- resistant variants}

The resistant phenotype of the variants has been inherited in a stable fashion for more than 10 months (about 300 generations) in continuous culture in the absence of dexamethasone, consistent with a mutational origin of these variants. The frequency with which colonies from the wild-type population form fibrinolytic plaques in the presence of dexamethasone, however, is high; i.e., greater than $10^{-3}$. This raises the question of whether or not resistance is due to genetic mutation. The standard technique for distinguishing between a stable variant phenotype which is induced by experimental conditions from that arising by random genetic events occurring prior to the selective conditions is the fluctuation test developed by Luria and Delbruck ('43). Because of the high frequency with which apparently resistant variants are observed in the wild-type population, the cells were first cloned in order to reduce the likelihood that any cell subcloned from this population is already a variant. Due to the variability between subclones of HTC cells in growth rates and plating efficiencies after trypsinizing and transferring cells to plates for the agar overlay, only a limited number of subclones were obtained in which the same number of cells were tested. Table 3 shows the data from such a fluctuation analysis. Although the differences in the number of cells of each subclone tested would tend to increase the variance between subclones, it is apparent that the variation is greater than can be due just to the differences in sample sizes. The variance between subclones is considerably greater than between samples of the original clone. Whereas the variance between samples of the original clone is only twice the mean, the variance between subclones is nearly 50 times greater than the mean. This argues that dexamethasone-resistant variants are not induced by dexamethasone but arise randomly prior to exposure to the hormone.

Another approach which has been used to obtain evidence for mutational origins of variant phenotypes is to show that mutagens increase the frequency of appearance of variants. Two different mutagens were chosen because of their different mechanisms of action. EMS acts by ethylating bases whereas ultraviolet light acts primarily by causing thymine dimers. Increasing concentrations of EMS that resulted in up to $91 \%$ cell killing, and exposure to UV that caused up to $86 \%$ cell killing failed to increase the number of variants. The failure to increase the number of variants using mutagens argues against the hypothesis that mutations are the primary cause of resistance to dexamethasone. 


\section{DISCUSSION}

HTC cells provide a useful model in which to study hormonal regulation. Glucocorticoids induce a number of cellular responses including several changes in membrane function. Variants selected because of their resistance to a specific glucocorticoid response would facilitate the study of that response. However, the lack of a selective system for isolating variants in cells in which growth is not altered by steroids has made the isolation of such resistant cells difficult. We report here the isolation of unique variant HTC cells which are highly resistant to the dexamethasone inhibition of plasminogen activator. We have used an agarfibrin overlay technique which allows the identification and recovery of colonies producing plasminogen activator in the presence of dexamethasone. The variants are resistant to concentrations of dexamethasone 1,000 times that necessary to completely inhibit protease activity in wild-type cells.

Fluctuation analyses using the agar-fibrin overlay technique support the hypothesis that the occurrence of the hormone-resistant phenotype is random and not induced by the experimental conditions. An accurate statistical estimate of the rate of occurrence of the variant phenotype, using data from the fluctuation analyses, has been difficult because of the problem in obtaining and analyzing enough subclones with the same number of cells. Using the median method of Lea and Coulson ('49) to calculate "mutation" rates gives an approximate estimate of 3.5-4.0 $\times 10^{-3} / \mathrm{cell} /$ generation. This is the rate of occurrence of plaque-forming colonies in the agar-fibrin overlay in the presence of dexamethasone, and includes colonies which do not demonstrate stable resistance to dexamethasone inhibition of plasminogen activator activity when retested as well as colonies which do demonstrate a highly stable resistance. Thus the actual rate of occurrence of stable dexamethasone-resistant variants must be considerably lower. There have been reports of variants occurring spontaneously at high frequencies $\left(10^{-3} / \mathrm{cell} /\right.$ generation) in other cell lines. Examples include immunoglobulin variants in mouse myeloma cells (Coffino and Scharff, '71) and S49 mouse lymphoma cells unresponsive to $\beta$ adrenergic agonists (Haga et al., '77).

Mutagens did not cause an increase in the frequency of the appearance of the resistant phenotype. However, HTC cells are heteroploid and karyotypically highly variable (Ben- edict et al., '72; Lyons and Thompson, '77; Thompson et al., '74). Thus variants might arise from chromosomal segregation events (Chasin and Urlaub, '75), and the high frequency with which dexamethasone-resistant variants are recovered could be due primarily to isolation of cells with specific, stably inherited chromosomal rearrangements. Variants could also arise at a low frequency (e.g., $10^{-7}$ ) due to mutation. Thus, even if mutagens increased the frequency of dexamethasone-resistant variants arising by mutation, this might not be detectable over the high frequency of variants resulting from chromosomal rearrangements. Unfortunately, it is not feasible to look for the presence or absence of specific chromosomes or chromosome rearrangements because it is not possible to differentiate rat chromosomes, even using banding techniques.

The dexamethasone-resistant phenotype of the seven variants chosen for analysis has remained stable after more than ten months in continuous culture in the absence of glucocorticoids. Thus, no matter what the origin of resistance is, the stable phenotype should prove useful in the biochemical analysis of the mechanism by which hormones regulate various membrane functions (Fredin et al., '79; Seifert and Gelehrter, '78).

The resistance in these variants is apparently not due to deficient or defective steroid-receptor function in that the variants show wild-type induction of tyrosine aminotransferase. In order for induction of transaminase to occur, an active steroid-receptor complex must enter the nucleus, bind to chromatin, and cause the accumulation of specific mRNA coding for tyrosine aminotransferase (Rousseau, '75; Gelehrter, '76). The lesion in these variants must therefore be at some step distal to the binding of hormone-receptor complexes to nuclear chromatin. This finding is in contrast to the great majority of glucocorticoid-resistant variant cell lines previously described (Pfahl et al., '78; Sibley and Tomkins, '74; Yamamoto et al., '76). Essentially all of these variants which have been analyzed show deficient or defective glucocorticoid receptors. However, Thompson et al. ('77) have recently described the isolation of variant HTC cells in which tyrosine aminotransferase is not inducible by dexamethasone, and in which glucocorticoid receptor function appears to be normal.

In order to study the interdependence of 
glucocorticoid regulation of different membrane phenotypes, dexamethasone inhibition of $\alpha$-aminoisobutyric acid transport was tested in the variants. Because six of seven variants show normal dexamethasone inhibition of $\alpha$-aminoisobutyric acid transport, it seems clear that the inhibition of amino acid transport is not secondary to an inhibition of plasminogen activator; i.e., it is not due to an inhibition of proteolytic removal or alteration of membrane proteins. Furthermore, because these variants are selectively resistant to the hormonal inhibition of plasminogen activator activity while retaining wild-type induction of tyrosine aminotransferase and inhibition of amino acid transport, it appears that these hormone-mediated responses are regulated independently and not in a coordinate fashion. One variant (Variant $A$ ) does show at least partial resistance to inhibition of $\alpha$-aminoisobutyric acid transport; the nature of the defect in this variant is not clear.

These variants can also be used to analyze the mechanism of dexamethasone regulation of other membrane properties such as the induction of adhesion in HTC cells. It is possible that the dexamethasone induction of adhesiveness is secondary to the decrease in protease activity which in turn would allow the accumulation of specific glycoproteins involved in adhesion. This hypothesis has been tested directly using these variants (Fredin et al., '79). Isolation of other variant cell lines resistant to specific hormone-mediated functions affecting different membrane properties should prove similarly useful.

\section{ACKNOWLEDGMENTS}

This research was supported by National Institutes of Health Grants GM 15419 and CA 22729. S. C. S. was supported by a predoctoral training grant, GM 00071, from the National Institutes of Health, and T. D. G. by a Faculty Research Award from The American Cancer Society.

\section{LITERATURE CITED}

Ballard, P., and G. M. Tomkins 1970 Glucocorticoidinduced alteration of the surface membrane of cultured hepatoma cells. J. Cell Biol., 47: 222-234.

Beers, W. H., S. Strickland and E. Reich 1975 Ovarian plasminogen activator: relationship to ovulation and hormonal regulation. Cell, 6: 387-394.

Benedict, W. F., D. W. Nebert and E. B. Thompson 1972 Expression of aryl hydrocarbon hydroxylase induction and suppression of tyrosine animotransferase induction in somatic cell hybrids. Proc. Nat. Acad. Sci. (U.S.A.), 69: 2179-2183.
Carlson, S. A., and T. D. Gelehrter 1977 Hormonal regulation of membrane phenotype. J. Supramol. Struct., 6: 325-331.

Chasin, L. A., and G. Urlaub 1975 Chromosome-wide event accompanies the expression of recessive mutations in tetraploid cells. Science, 187: 1091-1093.

Coffino, P., and M. D. Scharff 1971 Rate of somatic mutation in immunoglobin production by mouse myeloma cells. Proc. Nat. Acad. Sci. (U.S.A.), 68: 219-223.

Fredin, B., S. C. Seifert and T. D. Gelehrter 1979 Dexamethasone induction of adhesion in hepatoma cells: the role of plasminogen activator. Nature, 277: 312-313.

Gelehrter, T. D. 1976 Enzyme induction. N. Engl. J. Med., 294: 522-526, 589-595, 646-651.

Haga, T., E. M. Ross, H. J. Anderson and A. Gilman 1977 Adenylate cyclase permanently uncoupled from hormone receptors in a novel-variant of $\mathbf{S 4 9}$ mouse lymphoma cells. Proc. Nat. Acad. Sci. (U.S.A.), 74: 2016-2020.

Heaton, J. H., and T. D. Gelehrter 1977 Derepression of amino acid transport by amino acid starvation in rat hepatoma cells. J. Biol. Chem., 252: 2900-2907.

Jones, P., W. Benedict, S. Strickland and E. Reich 1975 Fibrin overlay methods for the detection of single transformed cells and colonies of transformed cells. Cell, 5 : 323-329.

Lea, D. E., and C. H. Coulson 1949 The distribution of the numbers of mutants in bacterial populations. Genetics, 49: $264-284$.

Lowry, O. H., N. J. Rosebrough, A. L. Farr and R. J. Randall 1951 Protein measurement with the Folin phenol reagent. J. Biol. Chem., 192: 265-275.

Luria, S. E., and M. Delbruck 1943 Mutations of bacteria from virus sensitivity to virus resistance. Genetics, 28: 491.511 .

Lyons, L. B., and E. B. Thompson 1977 Delayed malignancy and altered growth properties of somatic cell hybrids between rat hepatoma and mouse L-cells. J. Cell. Physiol., 90: 179.191.

McDonald, R. A., and T. D. Gelehrter 1977 Glucocorticoid inhibition of amino acid transport in rat hepatoma cells. Biochem. Biophys. Res. Comm., 78: 1304-1310.

Pfahl, M., R. J. Kelleher, Jr. and S. Bourgeois 1978 General features of steroid resistance in lymphoid cell lines. Mol. Cell. Endocrinol., 10: 193-207.

Risser, W. L., and T. D. Gelehrter 1973 Hormonal regulation of amino acid transport in rat hepatoma cells in tissue culture. J. Biol. Chem., 248: 1248-1254.

Rousseau, G. G. 1975 Interaction of steroids with hepatoma cells: molecular mechanisms of glucocorticoid hormone action. J. Steroid Biochem., 6: 75-89.

Seifert, S. C. 1978 Glucocorticoid Regulation of Plasminogen Activator in Rat Hepatoma Cells. Ph.D. Thesis, University of Michigan, Ann Arbor.

Seifert, S. C, and T. D. Gelehrter 1978 Mechanism of dexamethasone inhibition of plasminogen activator in rat hepatoma cells. Proc. Natl. Acad. Sci. (U.S.A.), 75: 6130-6133.

Sibley, C. H., and G. M. Tomkins 1974 Mechanisms of steroid resistance. Cell, 2: 221-227.

Spencer, C. J., and T. D. Gelehrter 1974 Pseudoisozymes of hepatic tyrosine aminotransferase. J. Biol. Chem., 249: 577-583.

Stanners, C. P., G. L. Elicieri and H. Green 1971 Two types of ribosomes in mouse-hamster hybrid cells. Nature, New Biology, 230: 52-54.

Strickland, S., and W. H. Beers 1976 Studies on the role of plasminogen activator in ovulation. J. Biol. Chem., 251: 5694-5702.

Thompson, E. B., D. Aviv and M. E. Lippman 1977 Analysis 
of enzyme induction by steroid in low-and high-inducing variants of HTC cells. Endocrinology, 100: 406-419.

Thompson, E. B., W. F. Benedict, I. S. Owens and D. W. Nebert 1974 Aryl hydrocarbon hydroxylase and tyrosine aminotransferase activities in somatic cell hybrids derived from hepatoma tissue culture (HTC) cells and 3 T 3 (mouse) benzo[a]pyrene-resistant cells. Biochem. Biophys. Res. Comm., 56: 605-610.

Thompson, E. B., and M. E. Lippman 1974 Mechanism of action of glucocorticoids. Metabolism, 23: 159-202.

Thompson, E. B., G. M. Tomkins and J. F. Curran 1966
Induction of tyrosine $\alpha$-ketoglutarate transaminase by steroid hormones in a newly established tissue culture cell line. Proc. Nat. Acad. Sci. (U.S.A.), 56: 296-303.

Wigler, M., J. P. Ford and I. B. Weinstein 1975 Glucocorticoid inhibition of the fibrinolytic activity in tumor cells. In: Proteases and Biological Control. E. Reich, D. Rifkin and E. Shaw, eds. Cold Spring Harbor Press, New York, pp. 849-858.

Yamamoto, K. R., U. Gehring, M. R. Stampfer and C. H. Sibley 1976 Genetic approaches to steroid hormone action. Rec. Prog. Hormone Res., 32: 3-23. 